\title{
Biosaintifika
}

Journal of Biology \& Biology Education

http://journal.unnes.ac.id/nju/index.php/biosaintifika

\section{Molecular Identification of Endophytic Fungi from Bark of Raru (Cotylelobium melanoxylon) that Produce the Antibacterial Compounds}

\author{
${ }^{\square}$ Uswatun Hasanah, Riwayati, Idramsa, Eko Prasetya \\ DOI: 10.15294/biosaintifika.v9i3.9424 \\ Department of Biology, Faculty of Mathematics and Natural Science, Universitas Negeri Medan, Indonesia
}

\section{History Article}

Received 4 April 2017

Approved 31 July 2017

Published 31 December 2017

\section{Keywords}

Antibacterial; Cotylelobium melanoxylon; Endophytic Fungi; ITS rDNA

\begin{abstract}
The Dipterocarpaceae plant, raru (Cotylelobium melanoxylon) is widespread in Southeast Asia. The bark of raru has been used by local communities in North Sumatera as antidiarrheal drugs due to its antibacterial compounds. The antibacterial activity of the raru's bark is induced by endophytic fungi that live in the region of the bark. This study aimed to identify the endophytic fungi-producer of antibacterial compounds in the bark of raru (C. melanoxylon) by means of molecular analysis. In general, endophytic fungi have the ability to inhibit the growth of pathogenic bacteria. Thirty-eight isolates of endophytic fungi were isolated from the bark of raru. Selection of isolates for antibacterial activity against Escherichia coli ATCC 35218 and Staphylococcus aureus ATCC 25923 used the dual culture assay. Selection using the dual culture assay yielded 6 endophytic fungal isolates that have the ability to inhibit the growth of test bacteria. EF10A sample was the most powerful isolate inhibiting the growth of both bacteria test. Those six bacteria molecularly identified used a sequence generated from ITS rDNA region. Based on rDNA ITS region sequences, isolate, the producers of the antibacterial compound were identified as Talaromyces cellulolyticus, Penicillium purpurogenum, Aspergillus sp., Trichoderma harzianum, and Aspergillus orizae. The results of this study can be used by researchers to explore more potential endophytic fungi in raru plants ( $C$. melanoxylon) as a source of medicine. The data obtained need to be supported by further research to isolate the bioactive compounds that can inhibit the growth of microbial pathogens.
\end{abstract}

\section{How to Cite}

Hasanah, U., Riwayati, R., Idramsa, I., \& Prasetya, E. (2017). Molecular Identification of Endophytic Fungi from Bark of Raru (Cotylelobium melanoxylon) that Produce the Antibacterial Compounds. Biosaintifika: Journal of Biology \& Biology Education, 9(3), 380-386.

(C) 2017 Universitas Negeri Semarang
Correspondence Author:

J1. Willem Iskandar, Pasar V, Medan Estate, 20221.

E-mail: uswatun.hasanah241@gmail.com
p-ISSN 2085-191X e-ISSN 2338-7610 


\section{INTRODUCTION}

Resistance to microbes become one of the major problems in the world. Therefore, it is necessary for research to find the new sources of bioactive compounds that can overcome the bacterial or fungal infection (Devi \& Wahab, 2012). Due to the development of resistance in pathogenic microbes, the need for new antibiotic sources has increased rapidly (Devi et al., 2012). Bioactive compounds can be obtained from several sources, including from plants, animals, microbes and marine organisms (Prihatiningtias \& Widyastuti, 2006). Plants are an important source of biologically active compounds in natural product research. Many plant species have been used in traditional healing and have been studied for pharmacological properties (Marcellano et al., 2017). Medicinal plants are known to host multiple endophytic fungi and engage in the production of active metabolite compounds (Alvin et al., 2014).

Indonesia is a country with a high biodiversity and broad tropical rain forests it becomes an advantage in the search for the source of bioactive compounds (Reddell \& Gordon, 2000). One source of bioactive compounds derived from microorganisms are endophytic fungi (Strobel, 2003). The endophytic fungus is a rich source of bioactive secondary metabolites (Tan \& Zou, 2001) and is one class of endophytic microbes which are most commonly found in nature. These fungi live in a symbiotic mutualism associated with its host plant (Strobel, 2003).

Endophytic fungi infect healthy plants in certain tissues without causing any signs of infection (Bacon \& White, 2000), then produce enzymes, secondary metabolites (Tan \& Zou, 2001), mycotoxins, and also antibiotics (Carroll, 1988) which can be beneficial for the physiology and ecology of host plants against diseases caused by plant pathogens. Instead, the endophytic fungi can obtain nutrients to complete the life cycle of the host plant (Petrini et al., 1993).

The bark of raru (Cotylelobium melanoxylon) is one source of antibacterial potential as a medicine and has been used in a long time by the local community. Local communities in North Sumatra have been utilizing the bark of raru to treat diarrheal diseases and diabetes (Soerianegara \& Lemmens, 1993). The bark of raru contains ampelopsin $\mathrm{F}$., isoampelopsin $\mathrm{F}$., E-viniferin, vaticanol A, E, G, lyoniresinol (Matsuda et al., 2009), and flavonoids as antidiabetic, tannins and saponins compounds (Pasaribu, 2010) which are useful as an antimicrobial (bacteria and viruses).
Escherichia coli (E. coli) and Staphylococcus aureus ( $S$. aureus) are two opportunistic pathogens that can cause infection in humans (Bachir \& Benali, 2012). E. coli is a common pathogenic bacterium toxic to food and causes some diseases in humans that extend from the gastrointestinal tract to the extraintestinal tract such as the urinary tract, bloodstream, and central nervous system (Croxen \& Finlay, 2010). S. aureus is a dangerous and versatile pathogen that can cause many different diseases, most commonly causing skin infections and respiratory infections (Otto, 2014). Both of these bacteria are commonly used in the bioactivity test of bioactive compounds.

Based on the above background, it is necessary to identify endophytic fungi on plants raru (C. melanoxylon) that can produce antibacterial compounds so that in the future it can be used as a source of medicine for humans. This study aimed to isolate and identify endophytic fungi on plants raru ( $C$. melanoxylon) producer of an antibacterial agent using test samples on pathogenic bacteria and molecular analysis of DNA sequences generated from ITS rDNA region.

\section{METHODS}

\section{Isolation of endophytic fungi from raru plants (C. melanoxylon)}

The Bark of raru plants was obtained from Sitahuis Village, Sibunga-bunga District, Central Tapanuli, North Sumatra Province. Raru's bark was in a beam-shaped cut for $15-20 \mathrm{~cm}$ long, 3-5 $\mathrm{cm}$ wide and $1-2 \mathrm{~cm}$ thick to be brought to the laboratory. Bark samples were then cleaned with flowing water. Bark samples were cut to a size of $1.0-1.5 \times 0.5-1.0 \mathrm{~cm}$, and placed on filter paper and dried at room temperature. Bark samples were sterilized using Hallman's method (Hallman et al., 2006) that the bark samples were soaked in $96 \%$ of ethanol solution for $1 \mathrm{~min}$, in sodium hypocloride solution for 5 minutes, and $70 \%$ of ethanol for 1 minute. Bark samples were passed on the through the flame and then rinsed with aqua-bidest twice and dried using sterile filter paper. Samples of bark were placed on PDA media (Potato Dextrose Agar) on petri dishes with the addition of amoxicillin. Each petri dish had 5 sample pieces of bark. Incubation was carried out at room temperature for 5-7 days until the fungal growth occurs.

\section{Isolate Selection for antibacterial activity \\ Antibacterial activity isolates of Escherichia coli ATCC 35218 and Staphylococcus aurous ATCC 25923 used the dual culture assay. Endophytic}


fungi and test bacteria were maintained in a petri dish with NA medium. Endophytic fungi were incubated for 1-2 days at room temperature while the test bacteria were incubated for 24 hours at a temperature of $30^{\circ} \mathrm{C}$. The wells are made on a medium containing test bacteria and filled with endophytic fungal isolates then incubated for 1-2 days at room temperature. Isolates with the clear limpid zone was an indicator of the ability of isolates to inhibit the growth of bacteria. The antibacterial activity was determined by measuring the inhibitory zone (clear zone) around the wells. The inhibition zone (clear zone) was measured and stated in millimeters. Isolates with the ability to inhibit the growth of pathogenic bacteria used for further research.

\section{Molecular identification of endophytic fungi isolates}

The endophytic fungi isolate and the potential of antibacterial activity were molecularly identified using the sequence generated from ITS rDNA region. Isolation of DNA was done by $\mathrm{Ge}$ neJET Specific DNA isolation kit. Amplification of rDNA ITS region of Endophytic fungi applied two universal primers of ITS1 (5'- TCC GTA GGT GAA CCT GCG G-3') and ITS4 (5' - TCC TCC GCT TAT TGA TAT GC -3') and by PCR (Polymerase Chain Reaction) machine of SensoQuest Labcycler. The condition of amplified gene fragment was pre-denaturation of the target DNA at $94^{\circ} \mathrm{C}$ for 5 minutes followed by 30 cycles at $94^{\circ} \mathrm{C}$ for one minute, primer annealing at $55^{\circ} \mathrm{C}$ for one minute and primer extension at $70^{\circ} \mathrm{C}$ for 2 minutes. PCR was ended with the temperature of $72^{\circ} \mathrm{C}$ for 10 minutes and followed by cooling until the temperature is $4^{\circ} \mathrm{C}$. PCR products were visualized by gel electrophoresis of $1.5 \%$ and SYBR Safe DNA gel stain for staining then measured by the ladder of $100 \mathrm{bp}$ - $1500 \mathrm{bp}$ utilizing 100 -volt electrophoresis machine for 45 minutes. Electrophoresis results were observed using UV Light Gel Documentation System (Biostep, Felix 2040). PCR result showed a clear band followed by sequencing using sequencing service of Genetics Science, First Base, Singapore.

The nucleotide order of ITS rDNA region sequencing results from endophytic fungi was compared with the collection of the ITS rDNA region at the National Center for Biotechnology Information (NCBI) (www.ncbi.nih.nim.gov). Program Basic Local Alignment Search (BLAST) was used to determine the types of isolates based on the GenBank database. Reconstruction of the phylogenetic tree was created using the MEGA 6 program by comparing the isolates with se- quential order of endophytic fungi ITS rDNA region obtained from the DNA database at NCBI GeneBank. The root position on the unrooted tree was estimated by using Rhizopus microsporus EU798703.1 (GeneBank) as the outgroup strain.

\section{RESULTS AND DISCUSSION}

Bioactivity assay of endophytic fungi isolates

A total of 38 isolates of endophytic fungi collected from bark of raru (C. melanoxylon). Bacteria that were used to determine the antibacterial compound-producing endophytic fungi were Escherichia coli (ATCC 35218) and Staphylococcus aureus (ATCC 25923). From a total of 38 isolates of endophytic fungi as the isolation result, only 6 endophytic fungi isolates were able to inhibit the growth of both test bacteria. Inhibition zone diameter of 6 isolates of the fungi are shown in Table 1.

Table 1. Zone diameter inhibiting the bacteria growth by fungi

\begin{tabular}{lcc}
\hline \multirow{2}{*}{ Isolate } & \multicolumn{2}{c}{ Inhibitory Zone } \\
\cline { 2 - 3 } & $\begin{array}{c}\text { E. coli }(\mathrm{ATCC} \\
\text { 35218) }(\mathrm{mm})\end{array}$ & $\begin{array}{c}\text { S. aureus }(\mathrm{ATCC} \\
\text { 25923) (mm) }\end{array}$ \\
\hline Sample EF2K & 10.26 & 7.1 \\
Sample EF8 & 7.1 & 6.96 \\
Sample EF2A & 3.93 & 3.9 \\
Sample EF10A & 10.53 & 7.2 \\
Sample EF10B & 7.33 & 7.13 \\
Sample EF3A & 7.3 & 7.03 \\
\hline
\end{tabular}

Table 1 shows that, six isolates of endophytic fungi have the ability to inhibit the growth of test bacteria. EF10A endophytic fungi isolates had the greatest inhibition zone while isolates EF2A had the smallest inhibitory zone against the E. coli and $S$. Aureus bacteria.

Endophytic fungi ability to inhibit microbial growth has been widely reported. Idramsa et al., (2015) reported that the isolated endophytic bacteria from $C$. melanoxylon has the ability to inhibit pathogenic bacteria such as Escherichia coli and Staphylococcus aureus. The isolated endophytic fungi from Quercus variabilis has the ability to inhibit the pathogenic fungi (Trichophyton rubrum, Candida albicans, Aspergillus niger, Epidermophyton floccosum, Microsporum canis, Cryptococcus neoformans) (Wang et al., 2007) and bacteria (Escherichia coli, Bacillus subtilis, Pseudomonas fluorescens) (Phongpaichit et al., 2006). The crude extract of isolated endophytic fungi from Spondias mombin inhibits the growth of actinomycetes, Saccharomy- 
ces cerevisiae, Geotrichum sp., Penicillium canadensis, Cladosporium elatum, and Mycotypha sp. (Rodrigues et al., 2000).

Endophytic fungi isolates were able to inhibit the growth of test bacteria because of the activities of secondary metabolites contained in the isolates. The ability of endophytic fungi producing secondary metabolites is a combination of the interaction between the endophytic fungi and the host plant (Tan \& Zou, 2001). The ability of isolates in inhibiting the growth of gram positive and negative bacteria showed that the isolates can produce the metabolites as an antibacterial agent (Black, 2002). Various metabolites compound produced by endophytic fungi affected the increase of the host plant resistance against the pathogens and environmental stress (Habibah \& Ambar, 2013). Dudeja et al. (2012) states that the composition of endophytic fungi is strongly influenced by environmental and host plants. Since the host affects the production of endophytic fungal metabolites, further studies on whether the biosynthesis of active metabolite compounds continues or ceases when the fungus is grown in vitro is also necessary to know the main cause of the biosynthesis of the metabolite compound in the fungus (Owen \& Hundley, 2004). The composition of endophytic fungi also depends on the interaction of pathogenic fungi and other microorganisms (Rubini et al., 2005).

Environmental conditions affect the diversity of endophyte that lives on its host (Vega et al., 2010). The existence of endophytic fungi is influenced by seasonality (Mahesh et al., 2005), environmental factors (Petrini et al., 1993), and the type of host plant tissues (Mahesh et al., 2005). Variability in the composition of endophyte on a host plant is based on the effect of the physiological condition of the host, even on the same observation area (González \& Tello, 2011). According to Arnold \& Lutzoni (2007), endophyte will increase the presence, diversity, and regional distribution of host plants if they are at high geographic area. Plant defense responses limit the population of endophytic microorganisms within plants (Rosenblueth \& Martinez-Romero, 2006).

The main advantage of endophytic fungi utilization in drug discovery is its diversity offering a new source of abundant metabolites (Marcellano et al., 2017). In addition, endophytic fungi can be used as an alternative compound isolated from plants that can reduce the use of a large number of plants that produce these compounds (Alvin et al., 2014).

\section{Molecular identification of isolates endophytic fungi}

The accuracy of molecular biology techniques used for genetic differentiation of species shows a very important advance in the identification of fungal species (Santos et al., 2017). Molecular identification is done by analyzing the isolates that have the ability to inhibit bacterial growth test based on ITS rDNA region sequence comparison (Petti et al., 2005). Furthermore, the obtained rDNA ITS sequence can be compared with the data available in the GenBank database (Magnani et al., 2005).

Phylogenetic analysis demonstrated that EF3A and EF8 isolates sample are the most closely aligned with Talaromyces cellulolyticus KM458826.1 (GeneBank) with 99\% of homology. EF10B identified sample is closest aligned with Penicillium purpurogenum JQ663996.1 (GeneBank) with $91 \%$ of homology. Identified EF2A sample is closest aligned with Aspergillus sp. KJ934699.1 (GeneBank) with $100 \%$ of homology and EF2K sample is closest aligned with Trichoderma harzianum JX473720.1 (GeneBank) with $99 \%$ of homology. EF10A sample is identified most closely aligned with Aspergillus orizae HQ285580.1 (GeneBank) with $99 \%$ of homology. Outgroup (Rhizopus microsporus) has a separate branch from endophytic fungi isolates (Figure 1).

Identification using ITS sequence analysis is generally used to identify the fungi to species level (Nilsson et al., 2008). Guo et al. (2000) use the ITS rDNA region sequences to identify Valsaceae, Mycosphaerellaceae, Xylariaceae, Clypeosphaeriaceae, and Dothideales of endophytic fungal isolates on Livistona chinensis ITS rDNA assay showed that endophytic fungi of 174 medicinal plants are identified as Altenaria, Phomopsis, Sporidesmium, Paecilomyces and Fusarium (Lin et al., 2007). ITS region has the highest probability of success for identifying the fungi in a broad range with the most obvious gap barcode on interspecific variation and intraspesific (Schoch et al., 2012).

Some members of Talaromyces have antibacterial abilities. Talaromyces islandicus, T. radicus, T. rugulosus, and T. wortmannii produce rugulosin which inhibits growth in Staphylococcus aureus and skyrin which has been reported as antitumor agents (Yamazaki et al., 2010). Talaromyces coalescens produces botryodiploidi which is a mycotoxin with antifungal, antibacterial, and insecticidal effects (Cabedo et al., 2007). Penicillium purpurogenum has the ability to inhibit the growth of bacterial E.coli, B. subtilis, P. aeruginosa, and $S$. aureus (Sharma et al., 2013). Aspergillus sp produc- 
es metabolites that exhibit the antibacterial activity against 6 pathogenic bacteria (Staphylococcus albus, Bacillus subtilis, Bacillus cereus, Sarcina lutea, Escherichia coli and Micrococcus tetragenus) and two marine strains (Vibrio parahaemolyticus and Vibrio anguilarrum) (Li et al., 2012). Aspergillus oryzae has been used in the food fermentation industry because it produces antibacterial compounds such as kojic acid and aspirochlorine (Leonard et al., 2013). Trichoderma harzianum is effective at various concentrations in inhibiting the activity of bacteria Staphylococcus aureus, Proteus, E. Coli, and Klebsiella (Leelavathi et al., 2014).

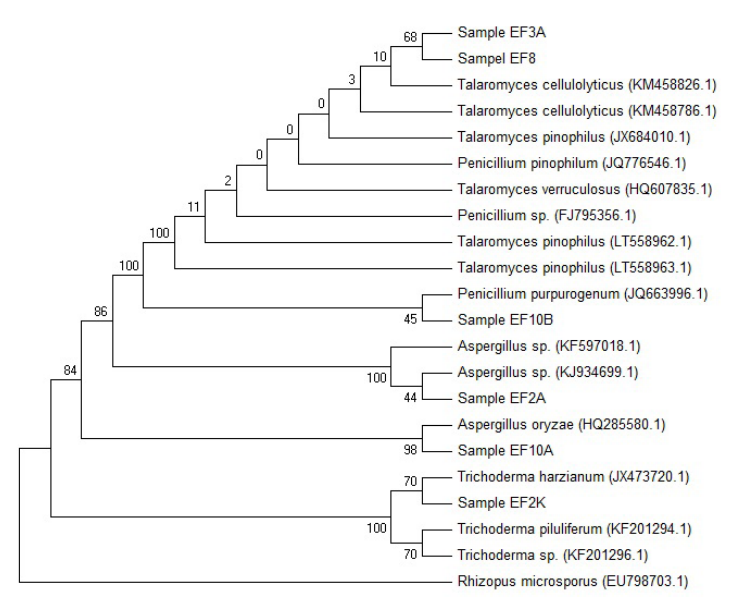

Figure 1. The phylogenetic tree showing the relationship between endophytic fungi isolates of C. melanoxylon with various types of endophytic fungi from the GeneBank based on ITS rDNA region sequences.

Indonesia has the world's largest tropical rainforest that offers incredible biodiversity, largely unexplored. Utilizing the traditional knowledge to study a plant that has been used as a medicinal source helps to narrow down the target plant with the potential of new antibacterial compounds. Many bioactive compounds in plants are actually produced by the interactions with their endophytes. Exploring the endophytes of this medicinal plant will help to isolate and produce its bioactive compounds. Efficient identification mechanism are essential for obtaining the endophytic fungi and its potential bioactive compounds. It will help to expand an antibacterial drug discovery from endophytic fungi of traditional medicinal plants.

\section{CONCLUSION}

Thirty-eight endophytic fungi were isolated from the bark of raru ( $C$. melanoxylon). Based on the selection using a dual culture assay, 6 iso- lates showed their ability to inhibit the growth of gram-negative bacteria (Escherichia coli ATCC 35218) and gram-positive bacteria (Staphylococcus aureus ATCC 25923). Based on rDNA ITS region sequences, isolates, the producer of antibacterial compounds agent were identified as Talaromyces cellulolyticus (EF3A and EF8; homology 99\%), Penicillium purpurogenum (EF10B; homology 91\%), Aspergillus sp. (EF2A; homology of $100 \%$ ), Trichoderma harzianum (EF2K; homology 99\%), and Aspergillus orizae (EF10A; homology 99\%).

\section{ACKNOWLEDGEMENT}

This research was supported by the Directorate General of Higher Education, Ministry of Research Technology and Higher Education, Republic of Indonesia in fundamental research grant scheme of year 2017 .

\section{REFERENCES}

Alvin, A., Miller, K. I. \& Neilan, B. A. (2014). Exploring the potential of endophytes from medicinal plants as sources of antimycobacterial compounds. Microbiological research, 169(7), 483495.

Arnold, A. E. \& Lutzoni, F. (2007). Diversity and host range of foliar fungal endophytes: are tropical leaves biodiversity hotspots? Ecology, 88(3), 541-549.

Bachir, R. G. \& Benali, M. (2012). Antibacterial activity of the essential oils from the leaves of Eucalyptus globulus against Escherichia coli and Staphylococcus aureus. Asian Pacific Journal of Tropical Biomedicine, 2(9), 39-742

Bacon, C. W. \& White, J. (2000). Microbial endophytes. Washington DC: CRC Press.

Black, J. G. (2002). Microbiology Principles and Exploration 5 th Ed.. USA: John Wiley \& Sons Inc.

Cabedo, N., López-Gresa, M.P., Primo, J., Ciavatta, M. L. \& González-Mas, M. C. (2007). Isolation and structural elucidation of eight new related analogues of the mycotoxin (-) botryodiplodin from Penicillium coalescens. Journal of agricultural and food chemistry, 55(17), 6977-6983.

Carroll, G. (1988). Fungal endophytes in stems and leaves: from latent pathogen to mutualistic symbiont. Ecology, 69(1), 2-9.

Croxen, M. A. \& Finlay, B. B. (2010). Molecular mechanisms of Escherichia coli pathogenicity. Nature reviews. Microbiology, 8(1), 26-38

Devi, N. N. \& Wahab, F. (2012). Antimicrobial properties of endophytic fungi isolated from medicinal plant Camellia sinesis. International Journal of Pharma and Bio Sciences, 3(3), 420-427.

Devi, P., Rodriguez, C., Naik, C. G. \& D'souza, L., (2012). Isolation and characterization of antibacterial compound from a mangrove-endo- 
phytic fungus, Penicillium chrysogenum MTCC 5108. Indian journal of microbiology, 52(4), 617623.

Dudeja, S. S., Giri, R., Saini, R., Suneja-Madan, P., \& Kothe, E. (2012). Interaction of endophytic microbes with legumes. Journal of Basic Microbiology, 52(3), 248-260.

González, V. \& Tello, M. L. (2011). The endophytic mycota associated with Vitis vinifera in central Spain. Fungal Diversity, 47(1), 29-42.

Guo, L. D., Hyde, K. D. \& Liew, E. C. Y. (2000). Identification of endophytic fungi from Livistona chinensis based on morphology and rDNA sequences. New Phytologist, 147(3), 617-630.

Habibah, N. A. \& Ambar, S. (2013). Optimasi sterilisasi permukaan daun dan eliminasi endofit pada burahol. Biosaintifika: Journal of Biology \& Biology Education, 5(2), 94-99.

Hallman, J., Berg, G. \& Schulz, B. (2006). Isolation procedures for endophytic microorganisms. In Microbial Root Endophytes. Berlin Heidelberg: Springer, 299-319.

Idramsa, Soetarto, E. S., Nugroho, L. H., Pratiwi, R. \& Prasetya, E. (2015). Endophytic bacteria inducing antibacterial synthesis of the bark of raru (Cotylelobium melanoxylon). European Journal of Experimental Biology, 5(9), 20-26.

Leelavathi, M. S., Vani, L. \& Reena, P. (2014). Antimicrobial activity of Trichoderma harzianum against bacteria and fungi. International Journal of Current Microbiology and Applied Sciences, 3(1), 96-103.

Leonard, C. A., Brown, S. D. \& Hayman, J. R. (2013). Random Mutagenesis of the Aspergillus oryzae Genome Results in Fungal Antibacterial Activity. International Journal of Microbiology, 2013, 1-5.

Li, D., Xu, Y., Shao, C. L., Yang, R. Y., Zheng, C. J., Chen, Y. Y. \& Wang, C. Y. (2012). Antibacterial bisabolane-type sesquiterpenoids from the sponge-derived fungus Aspergillus sp. Marine drugs, 10(1), 234-241.

Lin, X., Lu, C., Huang, Y., Zheng, Z., Su, W. \& Shen, Y. (2007). Endophytic fungi from a pharmaceutical plant, Camptotheca acuminata: isolation, identification and bioactivity. World Journal of Microbiology and Biotechnology, 23(7), 10371040.

Magnani, M., Fernandes, T., Prete, C. E. C., Homechim, M., Ono, E. Y. S., Vilas-Boas, L. A. \& Fungaro, M. H. P. (2005). Molecular identification of Aspergillus spp. isolated from coffee beans. Scientia Agricola, 62(1), 45-49.

Mahesh, B., Tejesvi, M. V., Nalini, M. S., Prakash, H. S., Kini, K. R., Subbiah, V. \& Shetty, H. S. (2005). Endophytic mycoflora of inner bark of Azadirachta indica. Current Science, 88(2), 218219.

Marcellano, J. P., Collanto, A. S. \& Fuentes, R. G. (2017). Antibacterial Activity of Endophytic Fungi Isolated from the Bark of Cinnamomum mercadoi. Pharmacognosy Journal, 9(3), 405-409.
Matsuda, H., Asao, Y., Nakamura, S., Hamao, M., Sugimoto, S., Hongo, M., Pongpiriyadacha, Y. \& Yoshikawa, M. (2009). Antidiabetogenic constituents from the Thai traditional medicine Cotylelobium melanoxylon. Chemical and Pharmaceutical Bulletin, 57(5), 487-494.

Nilsson, R. H., Kristiansson, E., Ryberg, M., Hallenberg, N. \& Larsson, K. (2008). Intraspecific ITS Variability in the Kingdom Fungi as Expressed in the International Sequence Databases and Its Implications for Molecular Species Identification. Evolutionary bioinformatics online, 4, 193-201.

Otto, M. (2014). Staphylococcus aureus toxins. Current Opinion in Microbiology, 17(1), 32-37

Owen, N. L. \& Hundley, N. (2004). Endophytes-the chemical synthesizers inside plants. Science progress. Science Progress, 87(2), 79-99.

Pasaribu, G. (2010). Inhibition activity of alpha glucosidase from several stem bark of raru. Jurnal Penelitian Hasil Hutan, 29(1), 10-19.

Petrini, O., Sieber, T. N., Toti, L. \& Viret, O. (1993). Ecology, metabolite production, and substrate utilization in endophytic fungi. Natural Toxins, 1(3), 185-196.

Petti, C. A., Polage, C. R. \& Schreckenberger, P. (2005). The role of 16S rRNA gene sequencing in identification of microorganisms misidentified by conventional methods. Journal of clinical microbiology, 43(12), 6123-6125.

Phongpaichit, S., Rungjindamai, N., Rukachaisirikul, V. \& Sakayaroj, J. (2006). Antimicrobial activity in cultures of endophytic fungi isolated from Garcinia species. FEMS Immunology \& Medical Microbiology, 48(3), 367-371.

Prihatiningtias, W. \& Widyastuti, S. M. (2006). Senyawa bioaktif fungi endofit akar kuning (Fibraurea chloroleuca Miers) sebagai agensia antimikroba. Doctoral dissertation. Yogyakarta: Universitas Gadjah Mada.

Reddell, P. \& Gordon, V. (2000). Lessons from nature: can ecology provide new leads in the search for novel bioactive chemicals from tropical rainforests? In Biodiversity: new leads for the pharmaceutical and agrochemical industries. UK: Royal Society of Chemistry.

Rodrigues, K. F., Hesse, M. \& Werner, C. (2000). Antimicrobial activities of secondary metabolites produced by endophytic fungi from Spondias mombin. Journal of basic microbiology, 40(4), 261267.

Rosenblueth, M. \& Martinez-Romero, E. (2006). Bacterial endophytes and their interactions with hosts. Molecular plant-microbe interactions, 19(8), 827-837.

Rubini, M. R., Silva-Ribeiro, R. T., Pomella, A. W., Maki, C. S., Araújo, W. L., Dos Santos, D. R. \& Azevedo, J. L. (2005). Diversity of endophytic fungal community of cacao (Theobroma cacao L.) and biological control of Crinipellis perniciosa, causal agent of Witches' Broom Disease. International Journal of Biological Sciences, 1(1), 
24-33.

Santos, M. S., Orlandelli, R. C., Polonio, J. C., dos Santos Ribeiro, M. A., Sarragiotto, M. H., Azevedo, J. L. \& Pamphile, J. A. (2017). Endophytes isolated from passion fruit plants: molecular identification, chemical characterization and antibacterial activity of secondary metabolites. Journal of Applied Pharmaceutical Science, 7(4), 38-43.

Schoch, C. L., Seifert, K. A., Huhndorf, S., Robert, V., Spouge, J. L., Levesque, C. A., Chen, W., Bolchacova, E., Voigt, K., Crous, P. W. \& Miller, A. N. (2012). Nuclear ribosomal internal transcribed spacer (ITS) region as a universal DNA barcode marker for Fungi. Proceedings of the $\mathrm{Na}$ tional Academy of Sciences, 109(16), 6241-6246.

Sharma, P., Kaul, P., Khetmalas, M. B. \& Tandon, G. D. (2013). Antibacterial, antialgal and $\beta$-lactamase inhibition activity of Penicillium purpurogenum var rubrisclerotium. Indian Journal of Research, 2(2), 17-19.

Soerianegara, I. \& Lemmens, R. H. M. J. (1993). Plant resources of southeast Asia. Timber Trees: Major Commercial Timbers, 5(1), 384-391.
Strobel, G. A. (2003). Endophytes as sources of bioactive products. Microbes and Infection, 5(6), 535544.

Tan, R. X. \& Zou, W. X. (2001). Endophytes: a rich source of functional metabolites. Natural Product Reports, 18(4), 448-459.

Vega, F. E., Simpkins, A., Aime, M. C., Posada, F., Peterson, S. W., Rehner, S. A., Infante, F., Castillo, A. \& Arnold, A. E. (2010). Fungal endophyte diversity in coffee plants from Colombia, Hawai'i, Mexico and Puerto Rico. Fungal Ecology, 3(3), 122-138.

Wang, F. W., Jiao, R. H., Cheng, A. B., Tan, S. H. \& Song, Y. C. (2007). Antimicrobial potentials of endophytic fungi residing in Quercus variabilis and brefeldin A obtained from Cladosporium sp. World Journal of Microbiology and Biotechnology, 23(1), 79-83.

Yamazaki, H., Omura, S. \& Tomoda, H. (2010). Xanthoradone $\mathrm{C}$, a new potentiator of imipenem activity against methicillin-resistant Staphylococcus aureus, produced by Penicillium radicum FKI-3765-2. Journal of Antibiotics, 63(6), 329330 . 